\title{
First Quarter Hanford Seismic Report for Fiscal Year 2000
}

\author{
D. C. Hartshorn \\ S. P. Reidel \\ A. C. Rohay
}

February 2000

Prepared for the U.S. Department of Energy

under Contract DE-AC06-76RLO 1830 


\title{
DISCLAIMER
}

This report was prepared as an account of work sponsored by an agency of the United States Government. Neither the United States Government nor any agency thereof, nor Battelle Memorial Institute, nor any of their employees, makes any warranty, express or implied, or assumes any legal liability or responsibility for the accuracy, completeness, or usefulness of any information, apparatus, product, or process disclosed, or represents that its use would not infringe privately owned rights. Reference herein to any specific commercial product, process, or service by trade name, trademark, manufacturer, or otherwise does not necessarily constitute or imply its endorsement, recommendation, or favoring by the United States Government or any agency thereof, or Battelle Memorial Institute. The views and opinions of authors expressed herein do not necessarily state or reflect those of the United States Government or any agency thereof.

\author{
PACIFIC NORTHWEST NATIONAL LABORATORY \\ operated by \\ BATTELLE \\ for the \\ UNITED STATES DEPARTMENT OF ENERGY \\ under Contract DE-AC06-76RLO 1830
}

\author{
Printed in the United States of America \\ Available to DOE and DOE contractors from the \\ Office of Scientific and Technical Information, P.O. Box 62, Oak Ridge, TN 37831; \\ prices available from $(615) 576-8401$.
}

Available to the public from the National Technical Information Service,

U.S. Department of Commerce, 5285 Port Royal Rd., Springfield, VA 22161

This document was printed on recycled paper. 
PNNL-11557-13

\section{First Quarter Hanford Seismic Report for Fiscal Year 2000}

D. C. Hartshorn

S. P. Reidel

A. C. Rohay

February 2000

Prepared for

the U.S. Department of Energy

under Contract DE-AC06-76RLO 1830

Pacific Northwest National Laboratory

Richland, Washington 99352 


\section{Summary}

Hanford Seismic Monitoring provides an uninterrupted collection of high-quality raw and processed seismic data from the Hanford Seismic Network (HSN) for the U.S. Department of Energy and its contractors. Hanford Seismic Monitoring also locates and identifies sources of seismic activity and monitors changes in the historical pattern of seismic activity at the Hanford Site. The data are compiled, archived, and published for use by the Hanford Site for waste management, Natural Phenomena Hazards assessments, and engineering design and construction. In addition, the seismic monitoring organization works with the Hanford Site Emergency Services Organization to provide assistance in the event of a significant earthquake on the Hanford Site.

The HSN and the Eastern Washington Regional Network (EWRN) consist of 42 individual sensor sites and 15 radio relay sites maintained by the Hanford Seismic Monitoring staff. The HSN uses 21 sites and the EWRN uses 36 sites; both networks share 16 sites. The networks have 46 combined data channels because Gable Butte and Frenchman Hills East are three-component sites. The reconfiguration of the telemetry and recording systems was completed during the first quarter. All leased telephone lines have been eliminated and radio telemetry is now used exclusively.

For the HSN, there were 311 triggers on two parallel detection and recording systems during the first quarter of fiscal year (FY) 2000. Twelve seismic events were located by the Hanford Seismic Network within the reporting region of $46^{\circ}-47^{\circ} \mathrm{N}$ latitude and $119^{\circ}-120^{\circ} \mathrm{W}$ longitude; 2 were earthquakes in the Columbia River Basalt Group, 3 were earthquakes in the pre-basalt sediments, 9 were earthquakes in the crystalline basement, and 1 was a quarry blast. Two earthquakes appear to be related to a major geologic structure, no earthquakes occurred in known swarm areas, and 9 earthquakes were random occurrences.

No earthquakes triggered the Hanford Strong Motion Accelerometers during the first quarter of FY 2000. 


\section{Acronyms}

$\begin{array}{ll}\text { BWIP } & \text { Basalt Waste Isolation Project } \\ \text { CRBG } & \text { Columbia River Basalt Group } \\ \text { DMIN } & \text { Closest distance from the epicenter to a station } \\ \text { DOE } & \text { U.S. Department of Energy } \\ \text { ETNA } & \text { Strong motion accelerometer manufactured by Kinemetrics } \\ \text { EWRN } & \text { Eastern Washington Regional Network } \\ \text { FY } & \text { Fiscal year } \\ \text { GAP } & \text { Largest gap in event-station azimuth distribution } \\ \text { GPS } & \text { Global Positioning System } \\ \text { HSN } & \text { Hanford Seismic Network } \\ M_{c} & \text { Coda Length Magnitude } \\ M_{L} & \text { Local Magnitude } \\ \text { NP } & \text { Number of p-wave and s-wave phases } \\ \text { NS } & \text { Number of stations } \\ \text { PNNL } & \text { Pacific Northwest National Laboratory } \\ \text { RMS } & \text { Root-mean-square residual } \\ \text { SMA } & \text { Strong motion accelerometer } \\ \text { USGS } & \text { United States Geological Survey } \\ \text { UTC } & \text { Universal Time, Coordinated } \\ \text { UW } & \text { University of Washington } \\ \text { WHC } & \text { Westinghouse Hanford Company } \\ \text { YFB } & \text { Yakima Fold Belt }\end{array}$




\section{Contents}

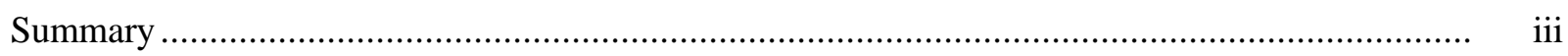

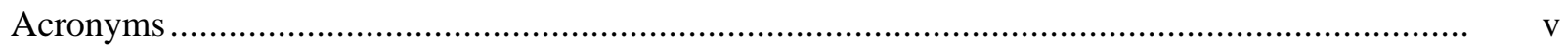

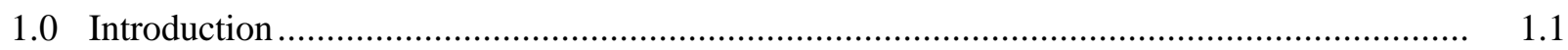

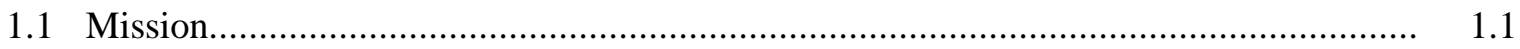

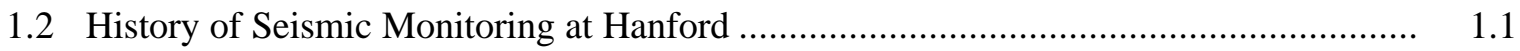

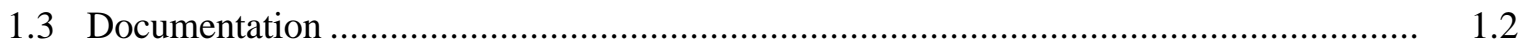

2.0 Network Operations......................................................................................... 2.1

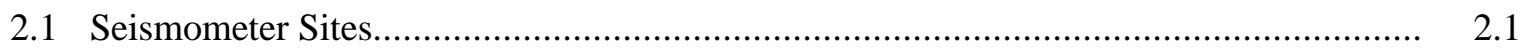

2.1.1 Station Maintenance .................................................................... 2.1

2.1.2 Data Acquisition ............................................................................... 2.1

2.2 Strong Motion Accelerometer Sites................................................................... 2.2

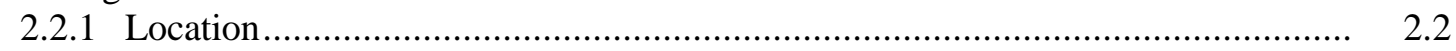

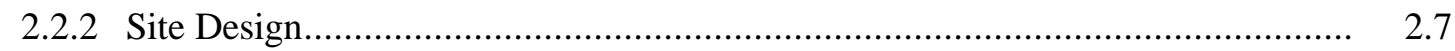

2.2.3 Strong Motion Accelerometer Operations Center....................................... 2.8

2.2.4 Strong Motion Operational Characteristics .............................................. 2.8

3.0 Magnitude, Velocity Models, and Quality Factors.................................................... 3.1

3.1 Coda Length Magnitude .............................................................................. 3.1

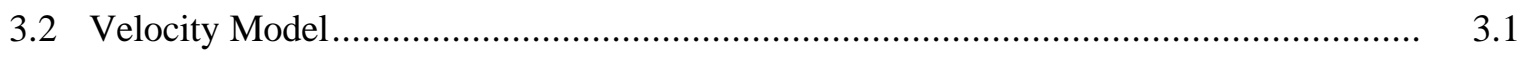

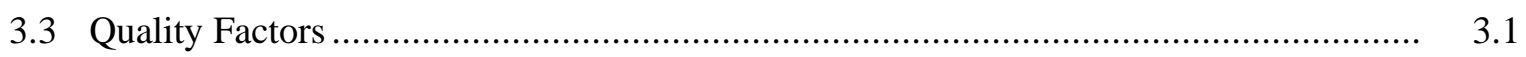

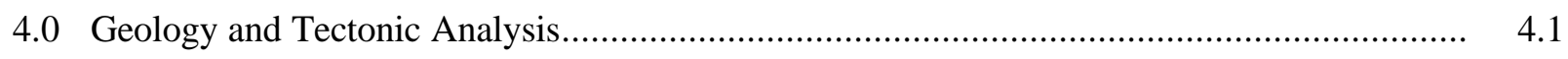

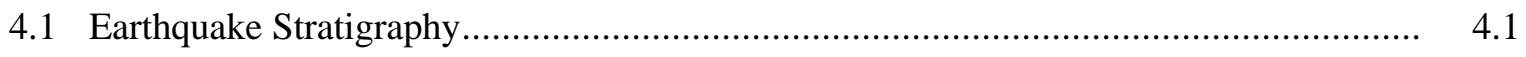

4.2 Geologic Structure Beneath the Monitored Area .................................................. 4.1

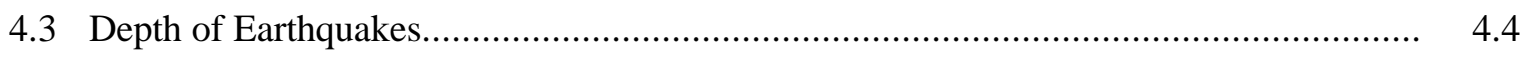

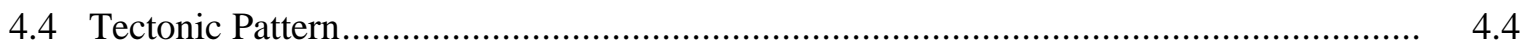

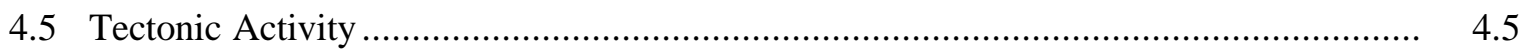

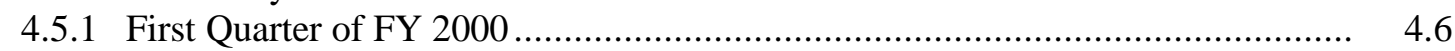

4.5.2 Earthquake Swarm Areas ........................................................................ 4.6

4.5.3 Random or Floating Events .................................................................. 4.6 
$5.0 \quad$ Strong Motion Accelerometer Operations …............................................................. 5.1

6.0 Capabilities in the Event of a Significant Earthquake .................................................. 6.1

6.1 Use of the SMA Network in the Event of an Earthquake .......................................... 6.1

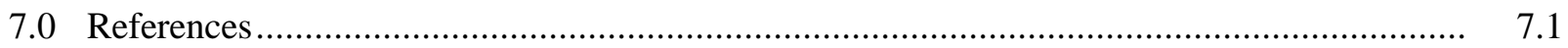




\section{Figures}

2.1 Locations of Seismograph Stations and Strong Motion Accelerometer Sites in the Hanford Seismic Network

2.2 Locations of Seismograph Stations in the Eastern Washington Regional Network

2.3 Schematic Diagram of a Strong Motion Accelerometer Installation

4.1 Structural and Tectonic Map of Columbia Basin Showing Major Seismic Source Structures

4.2 Geologic Cross Sections Through the Columbia Basin

4.3 Locations of All Events From October 1, 1999 Through December 31, 1999

\section{Tables}

2.1 Seismic Stations in the Hanford Seismic Network

2.2 Seismic Stations in the Eastern Washington Regional Network .....

2.3 Acquisition System Recorded Triggers

2.4 Free-Field Strong Motion Accelerometer Sites

2.5 Instrument Parameters for the Kinemetrics ETNA System in the Hanford SMA Network

3.1 Seismic Velocities for Columbia Basin Stratigraphy

3.2 Local Earthquake Data, October 1, 1999 Through December 31, 1999

4.1 Thickness of Stratigraphic Units in the Monitoring Area

4.2 Number of Local Earthquakes Occurring in Stratigraphic Units

4.3 Summary of Earthquake Locations. 


\subsection{Introduction}

\subsection{Mission}

The principal mission of seismic monitoring at the Hanford Site is to insure compliance with DOE Order 420.1, Facility Safety. This order establishes facility safety requirements related to nuclear safety design, criticality safety, fire protection, and natural phenomena hazards mitigation. With respect to seismic monitoring, the order states:

\subsubsection{Natural Phenomena Detection.}

Facilities or sites with hazardous materials shall have instrumentation or other means to detect and record the occurrence and severity of seismic events.

In addition, seismic monitoring provides an uninterrupted collection of high-quality raw seismic data from the Hanford Seismic Network (HSN) located on and around the Hanford Site, and provides interpretations of seismic events from the Hanford Site and vicinity. Hanford Seismic Monitoring locates and identifies sources of seismic activity, monitors changes in the historical pattern of seismic activity at the Hanford Site, and builds a "local" earthquake database (processed data) that is permanently archived. The focus of this report is the precise location of earthquakes proximal to or on the Hanford Site, specifically between 46 degrees and 47 degrees north latitude and between 119 degrees and 120 degrees west longitude. Data from the Eastern Washington Regional Network (EWRN) and other seismic networks in the northwest provide the Seismic Monitoring Project with necessary regional input for the seismic hazards analysis at the Hanford Site.

The seismic data are used by the Hanford Site contractors for waste management activities, Natural Phenomena Hazards assessments, and engineering design and construction. In addition, the Seismic Monitoring Project works with Hanford Site Emergency Services Organization to provide assistance in the event of a major earthquake on the Hanford Site.

\subsection{History of Seismic Monitoring at Hanford}

Seismic monitoring at the Hanford Site was established in 1969 by the United States Geological Survey (USGS) under a contract with the U.S. Atomic Energy Commission. In 1975, the University of Washington (UW) assumed responsibility for the network and subsequently expanded it. In 1979, the Basalt Waste Isolation Project (BWIP) became responsible for collecting seismic data for the Hanford Site as part of site characterization activities. Rockwell Hanford Operations followed by Westinghouse Hanford Company (WHC), operated the local network and were the contract technical advisors for the EWRN operated and maintained by the UW. Funding ended for BWIP in December 1988. Seismic monitoring and responsibility for the UW contract were then transferred to WHC's Environmental Division. Maintenance responsibilities for the EWRN were also assigned to WHC who made major upgrades to EWRN sites. 
Effective October 1, 1996, seismic monitoring was transferred to the Pacific Northwest National Laboratory (PNNL). ${ }^{1}$ Seismic monitoring is part of PNNL's Applied Geology and Geochemistry Group, Environmental Technology Division.

The Hanford Strong Motion Accelerometer (SMA) network was constructed during 1997 and came on line in May 1997. It operated continuously until September 30, 1997 when it was mothballed due to lack of funding. Funding was restored on October 1, 1998 by joint agreement between the U.S. Department of Energy (DOE) and PNNL. Operation of the free-field sites resumed on November 20, 1999.

\subsection{Documentation}

The Seismic Monitoring Project issues quarterly reports of local activity, an annual catalog of earthquake activity on and near the Hanford Site, and special-interest bulletins on local seismic events. The annual catalog includes the fourth quarter report for the fiscal year. Hanford Seismic Monitoring also provides information and special reports to other functions as requested. Earthquake information provided in these reports is subject to revisions if new data become available. In addition, an archive of all seismic data from the HSN is maintained by PNNL.

\footnotetext{
${ }^{1}$ Pacific Northwest National Laboratory is operated by Battelle Memorial Institute for the U.S. Department of Energy.
} 


\subsection{Network Operations}

\subsection{Seismometer Sites}

The seismic monitoring network consists of two designs of equipment and sites: seismometer sites and strong motion accelerometer (SMA) sites. Seismometer sites are designed to locate earthquakes and determine their magnitude and hypocenter location. SMA sites are designed to measure ground motion.

The HSN and the EWRN consists of 42 sensor sites. Most sites are in remote locations and require solar panels and batteries for power. The HSN uses 21 sites (Table 2.1 and Figure 2.1) and the EWRN uses 36 sites (Table 2.2 and Figure 2.2); both networks share 16 sites. The networks have 46 combined data channels because Gable Butte and Frenchman Hills East are three-component sites, each consisting of one vertical, one north-south horizontal, and one east-west horizontal data channel. Both networks use 15 additional telemetry relay sites. All sites or relays are transmitted to the Sigma V building, Richland Washington.

\subsubsection{Station Maintenance}

The HSN's maintenance records for the seismic sensor and relay sites are filed in the Hanford Seismic Monitoring office.

\subsubsection{Data Acquisition}

The signals from the seismometer sites are monitored for changes in signal amplitude that are expected from earthquakes. The seismic network is subdivided into spatial groupings of stations that are monitored for nearly simultaneous amplitude changes. When a change is detected, the recording system is triggered and a permanent record is made. The groupings and associated weighting schemes are designed to allow very small seismic events to be recorded and to minimize false triggers. Events are classified as locals (south-central Washington near the Hanford Site), regionals (Western U.S. and Canada), and teleseisms (from farther distances around the world). Local and regional events are usually earthquakes, but mining explosions are also recorded. The latter can usually be identified from wave characteristics, time of day, and through confirmation with local government agencies and industries. Frequently, military exercises at the Yakima Training Center produce a series of acoustic shocks that unavoidably trigger the recording system. Sonic booms and thunder also produce acoustic signals that trigger the recording system.

A PC-based system, adapted from a USGS program and the UW system, was implemented at Hanford during FY 1999. One new system has been in continuous operation since January 6, 1999. A second, backup PC system was installed in mid-March 1999, and both new systems have been running in parallel since that time. Although the two new systems are practically identical, there is enough granularity in the trigger timing that they sometimes record exclusive events. In nearly all cases, these exclusive triggers are "false" triggers, not earthquakes or quarry blasts (i.e., from acoustic sources). Barely 
Table 2.1. Seismic Stations in the Hanford Seismic Network

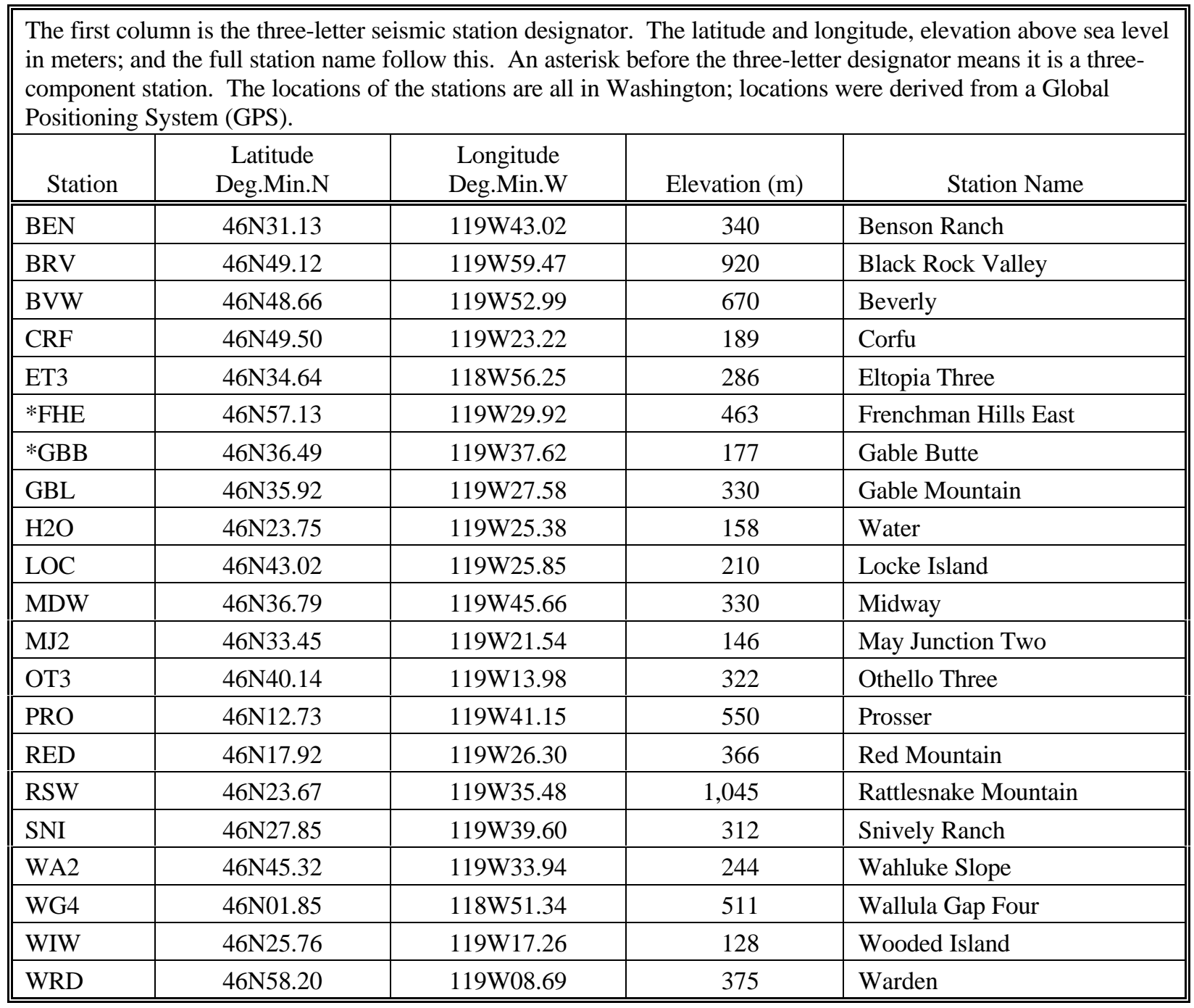

detectable, small signals from regional and teleseismic earthquakes account for the remainder of the exclusive triggers. Table 2.3 shows the number of each type of trigger for each quarter on the two systems.

\subsection{Strong Motion Accelerometer Sites}

\subsubsection{Location}

The Hanford SMA network consists of five free-field SMA sites (Figure 2.1) (Table 2.4). There is one free-field SMA located in each of the Separations Areas (200 Areas), one adjacent to the K-Basins in 100-K Area, one adjacent to the 400 Area where the Fast Flux Test Reactor is located, and one at the south end of the 300 Area. 


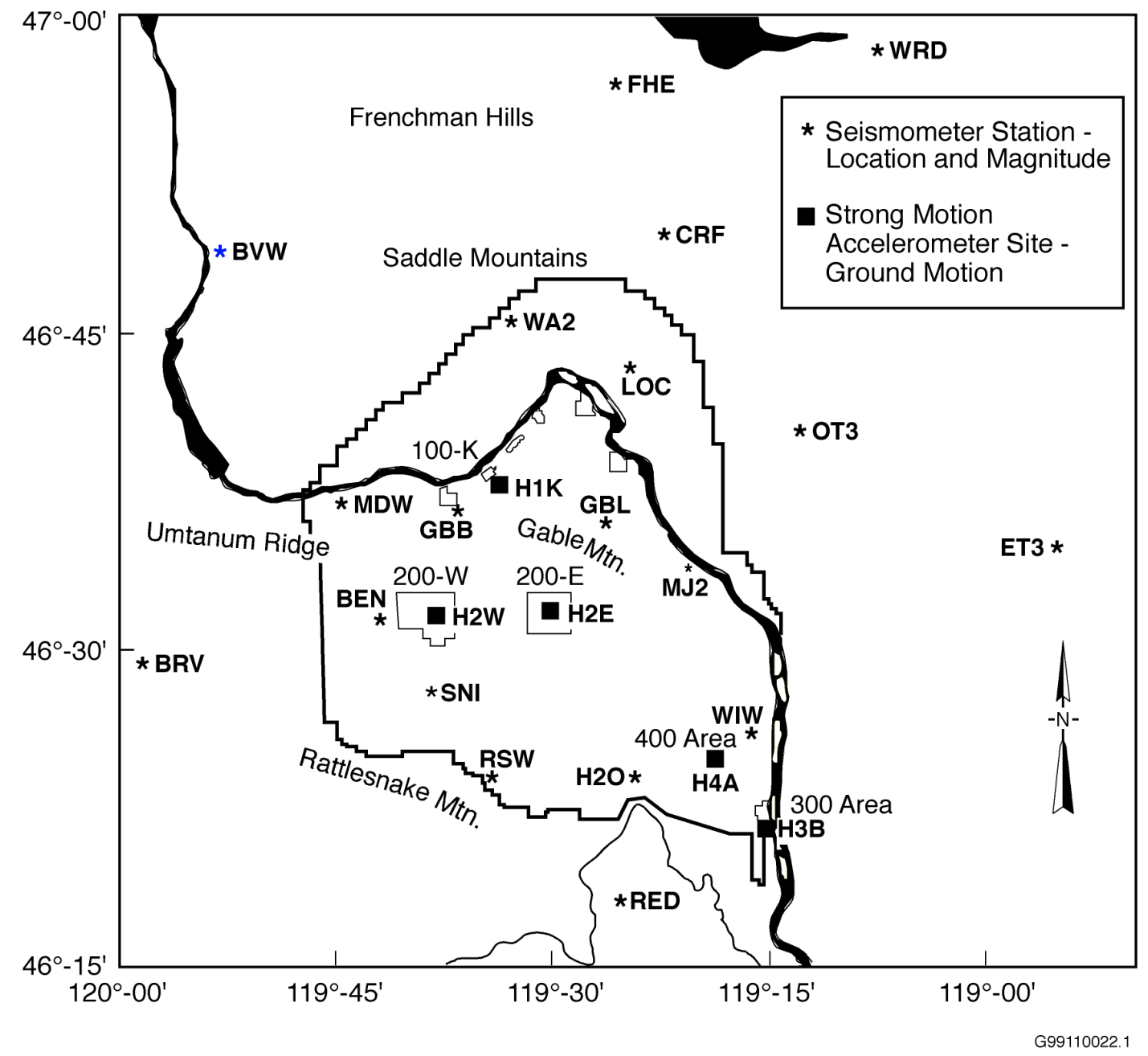

Figure 2.1. Locations of Seismograph Stations and Strong Motion Accelerometer Sites in the Hanford Seismic Network (see Table 2.1 for description of locations)

The instrumentation locations were chosen based on two criteria (Moore and Reidel 1996): 1) instruments should be located in areas having the highest densities of people; and 2) instruments should be located in areas having hazardous facilities. Some of the highest concentrations of employees at Hanford are 200 East and West Areas, 100-K Area, the Fast Flux Test Facility (400 Area), and the 300 Areas. The 200 Areas are where all high-level radioactive waste from past processing of fuel rods has been stored in single-shell and double-shell tanks. In addition, the Canister Storage Facility that will hold encapsulated spent fuel rods is being constructed in 200 East Area. The 100-K Area contains the K Basins where all spent fuel rods from the N Reactor are stored prior to encapsulation. The Cold Vacuum Drying Facility, located in the 100-K Area, will be used to encapsulate spent fuel rods from the K Basins prior to shipment to the Canister Storage Building in 200 East Area. 
Table 2.2. Seismic Stations in the Eastern Washington Regional Network

\begin{tabular}{|c|c|c|c|c|}
\hline \multicolumn{5}{|c|}{$\begin{array}{l}\text { The first column is the three-letter seismic station designator. The latitude and longitude, elevation above sea level } \\
\text { in meters; and the full station name follow this. An asterisk before the three-letter designator means it is a three- } \\
\text { component station. The locations of the stations are all in Washington unless otherwise indicated; locations were } \\
\text { determined from a Global Positioning System (GPS). }\end{array}$} \\
\hline Station & $\begin{array}{c}\text { Latitude } \\
\text { Deg.Min.N. }\end{array}$ & $\begin{array}{c}\text { Longitude } \\
\text { Deg.Min.W. }\end{array}$ & Elevation (m) & Station Name \\
\hline BRV & $46 \mathrm{~N} 29.12$ & 119W59.47 & 920 & Black Rock Valley \\
\hline BVW & $46 \mathrm{~N} 48.66$ & 119W52.99 & 670 & Beverly Washington \\
\hline CBS & $47 N 48.26$ & $120 \mathrm{~W} 02.50$ & 1,067 & Chelan Butte, South \\
\hline $\mathrm{CRF}$ & $46 N 49.50$ & 119W23.22 & 189 & Corfu \\
\hline DPW & $47 N 52.25$ & $118 \mathrm{~W} 12.17$ & 892 & Davenport \\
\hline DY2 & $47 N 59.11$ & $119 \mathrm{~W} 46.28$ & 890 & Dyer Hill Two \\
\hline ELL & $46 \mathrm{~N} 54.58$ & 120W33.98 & 789 & Ellensburg \\
\hline EPH & $47 \mathrm{~N} 21.38$ & 119W35.76 & 661 & Ephrata \\
\hline ET3 & $46 \mathrm{~N} 34.64$ & $118 \mathrm{~W} 56.25$ & 286 & Eltopia Three \\
\hline ETW & $47 \mathrm{~N} 36.26$ & 120W19.94 & 1,477 & Entiat \\
\hline$* \mathrm{FHE}$ & 46N57.13 & 119W29.92 & 463 & Frenchman Hills East \\
\hline$* \mathrm{GBL}$ & $46 \mathrm{~N} 35.92$ & 119W27.58 & 330 & Gable Mountain \\
\hline LNO & $45 \mathrm{~N} 52.31$ & $118 \mathrm{~W} 17.11$ & 771 & Lincton Mountain, Oregon \\
\hline LOC & $46 \mathrm{~N} 43.02$ & 119W25.85 & 210 & Locke Island \\
\hline MDW & $46 \mathrm{~N} 36.79$ & 119W45.66 & 330 & Midway \\
\hline $\mathrm{MJ} 2$ & $46 \mathrm{~N} 33.45$ & $119 \mathrm{~W} 21.54$ & 146 & May Junction Two \\
\hline MOX & $46 N 34.64$ & 120W17.89 & 501 & Moxee City \\
\hline NAC & $46 N 43.99$ & 120W49.42 & 728 & Naches \\
\hline NEL & $48 \mathrm{~N} 04.21$ & 120W20.41 & 1,500 & Nelson Butte \\
\hline OD2 & $47 \mathrm{~N} 23.26$ & $118 \mathrm{~W} 42.58$ & 553 & Odessa Two \\
\hline OT3 & $46 \mathrm{~N} 40.14$ & 119W13.98 & 322 & Othello Three \\
\hline PAT & $45 N 52.92$ & 119W45.14 & 262 & Paterson \\
\hline PRO & $46 \mathrm{~N} 12.73$ & 119W41.15 & 550 & Prosser \\
\hline RSW & $46 \mathrm{~N} 23.67$ & 119W35.48 & 1,045 & Rattlesnake Mountain \\
\hline SAW & $47 \mathrm{~N} 42.10$ & $119 \mathrm{~W} 24.03$ & 701 & St. Andrews \\
\hline SNI & $46 \mathrm{~N} 27.85$ & 119W39.60 & 312 & Snively Ranch \\
\hline TBM & $47 \mathrm{~N} 10.20$ & 120W35.88 & 1,006 & Table Mountain \\
\hline TRW & $46 \mathrm{~N} 17.32$ & 120W32.31 & 723 & Toppenish Ridge \\
\hline TWW & 47N08.29 & 120W52.10 & 1,027 & Teanaway \\
\hline VT2 & $46 \mathrm{~N} 58.04$ & 119W58.95 & 1,270 & Vantage Two \\
\hline WA2 & $46 \mathrm{~N} 45.32$ & 119W33.94 & 244 & Wahluke Slope Two \\
\hline WAT & $47 N 41.92$ & 119W57.24 & 821 & Waterville \\
\hline WG4 & $46 \mathrm{~N} 01.85$ & 118W51.34 & 511 & Wallula Gap Four \\
\hline WIW & $46 \mathrm{~N} 25.76$ & $119 \mathrm{~W} 17.26$ & 128 & Wooded Island \\
\hline WRD & $46 N 58.20$ & 119W08.69 & 375 & Warden \\
\hline YA2 & $46 \mathrm{~N} 31.60$ & $120 \mathrm{~W} 31.80$ & 652 & Yakima Two \\
\hline
\end{tabular}




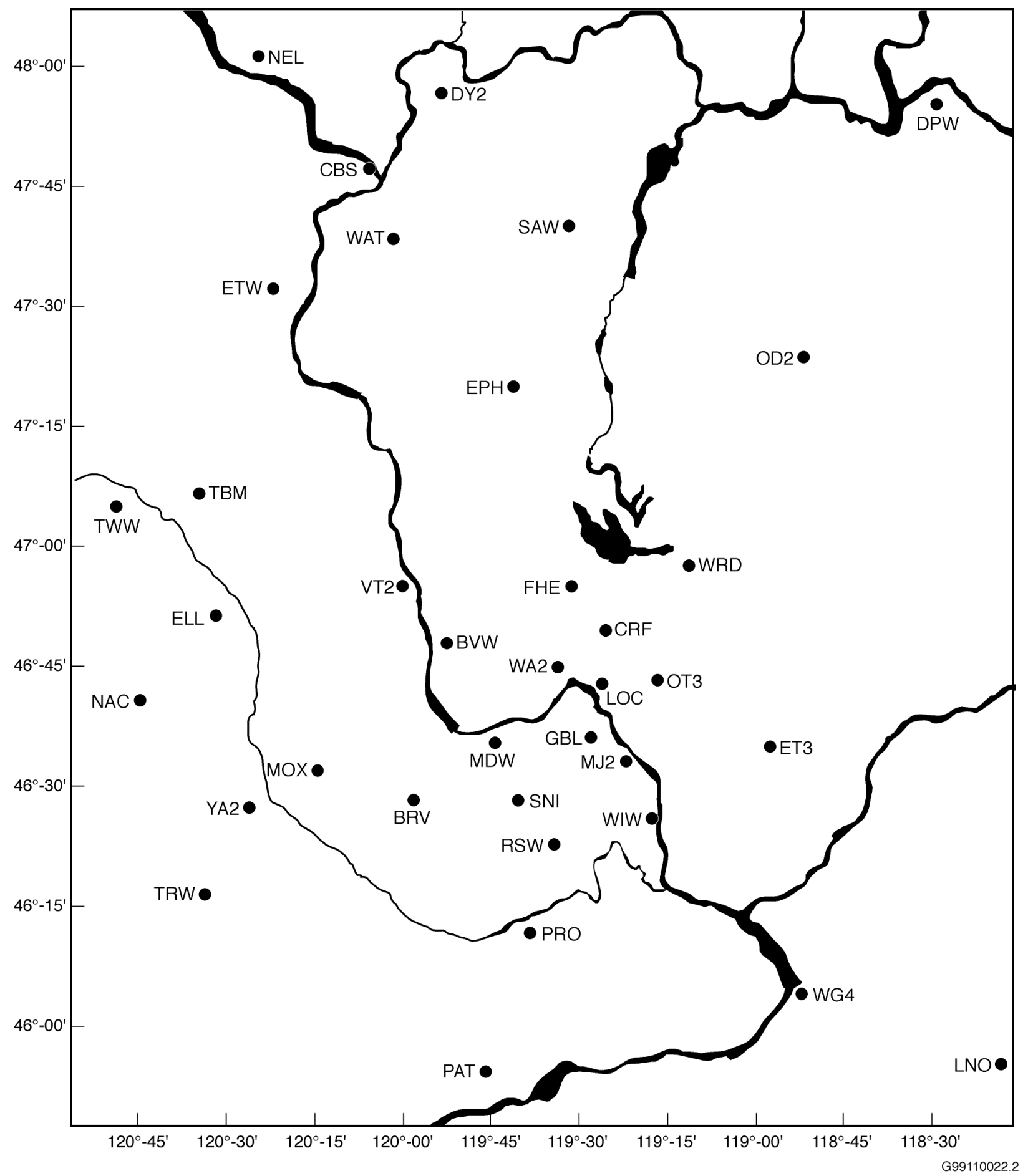

Figure 2.2. Locations of Seismograph Stations in the Eastern Washington Regional Network (see Table 2.2 for location descriptions) 
Table 2.3. Acquisition System Recorded Triggers

\begin{tabular}{|c|c|c|c|c|c|c|}
\hline \multirow[b]{2}{*}{ Event Type } & \multicolumn{2}{|c|}{$\begin{array}{c}\text { First } \\
\text { Quarter }\end{array}$} & \multirow{2}{*}{$\begin{array}{l}\text { Second } \\
\text { Quarter }\end{array}$} & \multirow{2}{*}{$\begin{array}{l}\text { Third } \\
\text { Quarter }\end{array}$} & \multirow{2}{*}{$\begin{array}{l}\text { Fourth } \\
\text { Quarter }\end{array}$} & \multirow[b]{2}{*}{ Remarks } \\
\hline & A & $\mathrm{B}$ & & & & \\
\hline $\begin{array}{l}\text { Southcentral } \\
\text { Washington }\end{array}$ & 20 & 19 & - & - & - & $\begin{array}{l}\text { Seismic events in southcentral Washington and } \\
\text { northcentral Oregon that triggered the HSN }\end{array}$ \\
\hline Regional & 26 & 23 & - & - & - & $\begin{array}{l}\text { Seismic events in the Western United States and } \\
\text { Canada }\end{array}$ \\
\hline Teleseism & 56 & 57 & - & - & - & $\begin{array}{l}\text { Seismic events at farther distances from around } \\
\text { the world }\end{array}$ \\
\hline Acoustic & 0 & 0 & - & - & - & $\begin{array}{l}\text { Acoustical shock waves from artillery, thunder, } \\
\text { and high-performance aircraft sonic booms }\end{array}$ \\
\hline Noise & 50 & 60 & - & - & - & $\begin{array}{l}\text { Triggers caused by data line circuits, lightning, } \\
\text { maintenance triggers during system testing, high } \\
\text { winds, coincidental noise at multiple sites within } \\
\text { a trigger subnet, etc. }\end{array}$ \\
\hline $\begin{array}{l}\text { Total } \\
\text { Triggers }\end{array}$ & 152 & 159 & - & - & - & $\begin{array}{l}\text { A total of } 311 \text { triggers were examined this } \\
\text { quarter. }\end{array}$ \\
\hline Local & & 2 & - & - & - & $\begin{array}{l}\text { Seismic events within the } 46-47 \text { degrees north } \\
\text { latitude and } 119-120 \text { degrees west longitude }\end{array}$ \\
\hline
\end{tabular}

Table 2.4. Free-Field Strong Motion Accelerometer Sites

\begin{tabular}{||l|l|l|l||}
\hline \multicolumn{1}{|c|}{ Site } & $\begin{array}{c}\text { Site } \\
\text { ID }\end{array}$ & \multicolumn{1}{c||}{$\begin{array}{c}\text { Latitude } \\
\text { Longitude } \\
\text { Elevation }\end{array}$} \\
\hline \hline 100-K Area & H1K & South of K Basins outside 100 Area fence lines. & $\begin{array}{l}46^{\circ} 38.51^{\prime} \\
119^{\circ} 35.53^{\prime} \\
152 \mathrm{~m}\end{array}$ \\
\hline $\begin{array}{l}\text { 200 East } \\
\text { Area }\end{array}$ & H2E & $\begin{array}{l}\text { East of B Plant; north of 7th street and east of } \\
\text { Baltimore Ave. }\end{array}$ & $\begin{array}{l}46^{\circ} 33.58^{\prime} \\
119^{\circ} 32.00^{\prime} \\
210 \mathrm{~m}\end{array}$ \\
\hline 200 West & H2W & $\begin{array}{l}\text { Northeast of Plutonium Finishing Plant (PFP); north } \\
\text { of 19th street and east of Camden Ave. }\end{array}$ & $\begin{array}{l}46^{\circ} 33.23^{\prime} \\
119^{\circ} 37.51^{\prime} \\
206\end{array}$ \\
\hline 300 Area & H3A & $\begin{array}{l}\text { South end of 300 Area inside fence lines. (NE 1/4, } \\
\text { SW 1/4, Sec. 11, T10N, R28E). }\end{array}$ & $\begin{array}{l}46^{\circ} 21.83^{\prime} \\
119^{\circ} 16.55^{\prime} \\
119 \mathrm{~m}\end{array}$ \\
\hline 400 Area & H4A & $\begin{array}{l}\text { 500 feet from fence line on east side of facility and } \\
\text { north of parking area). }\end{array}$ & $\begin{array}{l}46^{\circ} 26.13^{\prime} \\
119^{\circ} 21.30^{\prime} \\
171 \mathrm{~m}\end{array}$ \\
\hline
\end{tabular}




\subsubsection{Site Design}

All free-field SMA sites consist of two 30-gallon drums set in the ground such that the base of the drum is about 1 meter below the surface. One drum houses only the SMA; the other drum houses the electronics and communications equipment. A distance of 1 to 2.16 meters (40 to 85 inches) separates the drum containing the electronics and communications equipment from the SMA drum; a sealed conduit connects the two drums.

The SMA instruments are three-component units consisting of one vertical, one north-south horizontal, and one east-west horizontal data channel. The instruments in use are the ETNA ${ }^{\mathrm{TM}}$ system (registered trademark of Kinemetrics, Inc.). Instrument specifications are summarized in Table 2.5. In addition to the three-component SMA's, each ETNA SMA unit contains a computer, Global Positioning System (GPS) receiver and a modem (Figure 2.3). These systems are housed in a watertight box.

Two 100 amp-hour batteries that are housed in the equipment and communications drum (Figure 2.3) power the SMAs. The batteries are charged by four solar panels; a regulator is located between the solar panels and the batteries.

Table 2.5. Instrument Parameters for the Kinemetrics ETNA System in the Hanford SMA Network

\begin{tabular}{||l|l||}
\hline \multicolumn{1}{||c||}{ Parameter } & \multicolumn{1}{c|}{ Value or Range } \\
\hline \hline Sensor & $\begin{array}{l}\text { Tri-axial Force Balance Accelerometer orthogonally } \\
\text { oriented with internal standard }\end{array}$ \\
\hline Type & $\pm 2 \mathrm{~g}^{(\mathrm{a})}$ \\
\hline Full Scale & $0-50 \mathrm{~Hz}$ \\
\hline Frequency Range & approximately $70 \% \mathrm{critical}^{(\mathrm{a})}$ \\
\hline Damping & \multicolumn{2}{|l||}{} \\
\hline Data Acquisition & 3 \\
\hline Number of Channels & 18 -bit resolution @ 200 samples/second \\
\hline Sample Rate & Real-time, RS-232 Output Stream \\
\hline Digital Output & \multicolumn{2}{|l||}{} \\
\hline Seismic Trigger & $0.1-12.5 \mathrm{~Hz}$ \\
\hline Filter & $0.05 \%-0.20 \% \mathrm{~g}{ }^{(\mathrm{b})}$ \\
\hline Trigger level & $4.00 \% \mathrm{~g}$ \\
\hline Alarm (call-out) Threshold & $10 \mathrm{sec}$ \\
\hline Pre-event Memory & $40 \mathrm{sec}$ \\
\hline Post-event Time & $\begin{array}{l}\text { (a) Setting is dependent on instrument calibration. } \\
\text { (b) See Section 2.2.4 for discussion of trigger thresholds. }\end{array}$ \\
\hline
\end{tabular}




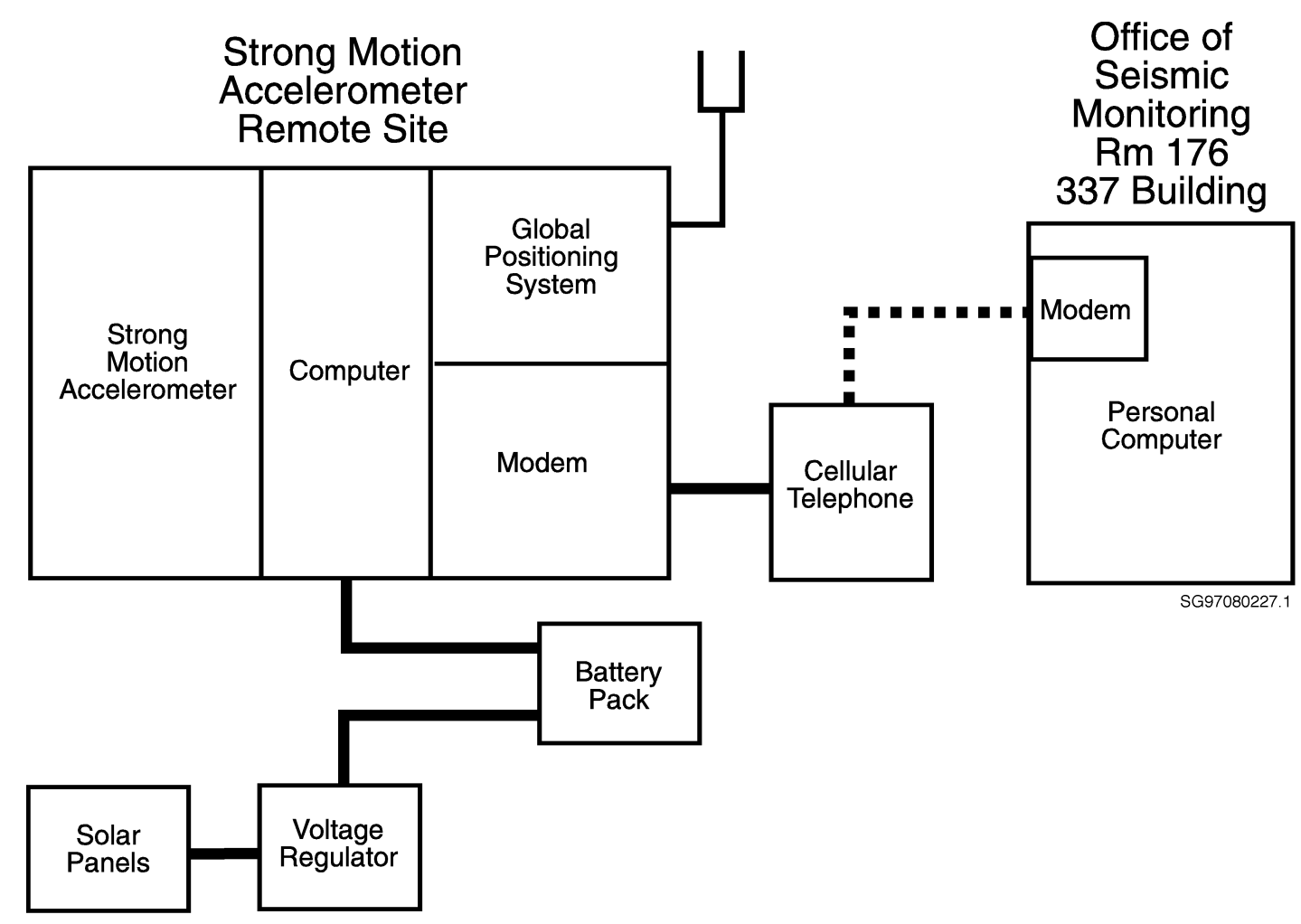

Figure 2.3. Schematic Diagram of a Strong Motion Accelerometer Installation

The communication link between the SMAs and the data analysis computer system housed in the Sigma V building is a cellular telephone/modem connection. The built-in modem in the SMA allows the system to use a cellular telephone to call an accelerometer or for the accelerometer to call out in the event it is triggered.

The SMAs have an internal GPS receiver used principally to link it to the National Bureau of Standards timing system. The GPS is internally activated approximately every 4 hours and checks the "location of the instrument" and the time. Any differences between the internal clock and the GPS time are recorded and saved by the SMA. Any corrections to the internal timing are made automatically. The greatest correction recorded was approximately 4 milliseconds.

\subsubsection{Strong Motion Accelerometer Operations Center}

The combined operations, data recording, data interpretation, and maintenance facility is located in the Sigma V building and is operated by the PNNL Seismic Monitoring Team.

\subsubsection{Strong Motion Operational Characteristics}

The signals from the three accelerometer channels at each site are digitized with a 24-bit digitizer and temporarily stored in a memory buffer. The sampling rate of the digitizer is set to $200 \mathrm{~Hz}$. The three 
channels are monitored for signals that equal or exceed a programmable trigger threshold. When one accelerometer channel is triggered, the other channels automatically record. The nominal threshold used is $0.05 \%$ of the full-scale range of $2.0 \mathrm{~g}$ ( $\mathrm{g}$ is the acceleration of gravity, $9.8 \mathrm{~m} / \mathrm{s}^{2}$ or $32 \mathrm{ft} / \mathrm{s}^{2}$ ) or $0.001 \mathrm{~g}$. Threshold trigger levels are monitored and are being adjusted to trigger infrequently on the noise sources (e.g., vehicles, sonic booms) near each site. This will provide ground motion data for smaller, nondamaging earthquakes that can be useful in estimating the ground motion expected from larger earthquakes, and to confirm correct operation of the instruments by analyzing the smaller-amplitude triggers. The recorders store information for 10 seconds before the trigger threshold is exceeded and for 40 seconds after the trigger ceases to be exceeded.

The SMA network is designed to transmit the data to the Hanford Seismic Recording Center at the Sigma V building or to be remotely accessed with a PC and modem. In addition, all SMAs can be accessed in the field where the data can be downloaded and interpreted. 


\subsection{Magnitude, Velocity Models, and Quality Factors}

\subsection{Coda Length Magnitude}

Coda-length magnitude $\left(M_{c}\right)$, an estimate of local magnitude $\left(M_{L}\right)$ (Richter 1958), is calculated using the coda-length/magnitude relationship determined for Washington State by Crosson (1972).

\subsection{Velocity Model}

The program XPED uses the velocities and layer depths given in Table 3.1. XPED was developed at the UW and the velocity model used in XPED is based on Rohay et al. (1985). XPED is an interactive earthquake seismogram display program used to analyze seismic events.

\subsection{Quality Factors (Q)}

XPED assigns a two-letter Quality factor (Table 3.2) that indicates the general reliability of the solution (A is best quality, D is worst). Similar quality factors are used by the USGS for events located with the computer program HYPO71. The first letter of the quality code is a measure of the hypocenter quality based primarily on travel time residuals. For example: Quality A requires a root-mean-square residual (RMS) less than 0.15 seconds while a RMS of 0.5 seconds or more is $\mathbf{D}$ quality (other estimates of the location uncertainty also affect this quality parameter). The second letter of the quality code is related to the spatial distribution of stations that contribute to the event's location, including the number of stations (NS), the number of p-wave and s-wave phases (NP), the largest gap in event-station azimuth distribution (GAP), and the closest distance from the epicenter to a station (DMIN). Quality A requires a solution with $\mathbf{N P}>8, \mathbf{G A P}<90^{\circ}$, and DMIN $<5 \mathrm{~km}$ (or the hypocenter depth if it is greater than $5 \mathrm{~km}$ ). If $\mathbf{N P} \leq 5$, GAP $>180^{\circ}$, or DMIN $>50 \mathrm{~km}$, the solution is assigned Quality $\mathbf{D}$.

Table 3.1. Seismic Velocities for Columbia Basin Stratigraphy (from Rohay et al. 1985)

\begin{tabular}{||c|l|c||}
\hline $\begin{array}{c}\text { Depth to Top of Velocity } \\
\text { Layer }(\mathrm{km})\end{array}$ & \multicolumn{1}{|c||}{ Stratigraphy } & $\begin{array}{c}\text { Velocity } \\
(\mathrm{km} / \mathrm{sec})\end{array}$ \\
\hline \hline 0.0 & $\begin{array}{l}\text { Saddle Mountains and Wanapum Basalts and intercalated } \\
\text { Ellensburg Formation }\end{array}$ & 3.7 \\
\hline 0.4 & Grande Ronde Basalt and pre-basalt sediments & 5.2 \\
\hline 8.5 & Crystalline Basement, Layer 1 & 6.1 \\
\hline 13.0 & Crystalline Basement, Layer 2 & 6.4 \\
\hline 23.0 & Sub-basement & 7.1 \\
\hline 38.0 & Mantle & 7.9 \\
\hline
\end{tabular}


Table 3.2. Local Earthquake Data, October 1, 1999 Through December 31, 1999

\begin{tabular}{|c|c|c|c|c|c|c|c|c|c|c|c|c|c|}
\hline Event ID & Type & Date & Time & Latitude & Longitude & Depth & Mag & NS/NP & Gap & DMIN & RMS & Q & Location \\
\hline 9910172141 & & $99 / 10 / 17$ & $21: 42: 18.75$ & $46 \mathrm{~N} 19.47$ & 119W47.17 & 6.69 & 1.4 & $6 / 09$ & 215 & 14 & 0.14 & $\mathrm{BD}$ & $13.1 \mathrm{~km} \mathrm{~N}$ of Prosser \\
\hline 9910182316 & $\mathrm{P}$ & $99 / 10 / 18$ & 23:17:17.80 & $46 \mathrm{~N} 16.85$ & 119W25.09 & 0.05 & 2.3 & $12 / 12$ & 178 & 2 & 0.26 & $\mathrm{BC}$ & $9.8 \mathrm{~km} \mathrm{~W}$ of Richland \\
\hline 9910271006 & & $99 / 10 / 27$ & $10: 06: 48.41$ & $46 \mathrm{~N} 26.73$ & 119W38.38 & 18.64 & 0.6 & $8 / 12$ & 176 & 2 & 0.09 & $\mathrm{AC}$ & $12.5 \mathrm{~km} \mathrm{~S}$ of $200 \mathrm{West}$ \\
\hline $9910311934 *$ & & $99 / 10 / 31$ & $19: 34: 27.01$ & $46 \mathrm{~N} 28.73$ & $119 \mathrm{~W} 42.62$ & 18.35 & 0.8 & $13 / 16$ & 136 & 13 & 0.17 & $\mathrm{BC}$ & $10.4 \mathrm{~km} \mathrm{SSW}$ of $200 \mathrm{West}$ \\
\hline 9911080404 & & $99 / 11 / 08$ & 04:05:10.20 & $46 \mathrm{~N} 34.47$ & $119 \mathrm{~W} 19.40$ & 14.69 & 0.2 & $11 / 16$ & 136 & 10 & 0.09 & $\mathrm{AC}$ & $15.7 \mathrm{~km} \mathrm{~N}$ of 400 Area \\
\hline 9911122219 & & $99 / 11 / 12$ & $22: 19: 37.90$ & $46 \mathrm{~N} 09.82$ & 119W13.56 & 0.04 & 0.8 & $10 / 12$ & 287 & 22 & 0.15 & $\mathrm{BD}$ & $9.1 \mathrm{~km}$ WSW of Kennewick \\
\hline 9911130323 & & $99 / 11 / 13$ & 03:23:48.06 & $46 \mathrm{~N} 41.71$ & 119W29.47 & 12.03 & 0.1 & $12 / 17$ & 73 & 8 & 0.08 & AA & $10.0 \mathrm{~km} \mathrm{NE}$ of $100-\mathrm{K}$ Area \\
\hline 9911211323 & & $99 / 11 / 21$ & $13: 23: 40.03$ & $46 \mathrm{~N} 35.25$ & 119W39.18 & 18.22 & 1.6 & $23 / 30$ & 76 & 3 & 0.15 & AA & $3.5 \mathrm{~km} \mathrm{NNW}$ of 200 West \\
\hline 9911211324 & & $99 / 11 / 21$ & $13: 24: 43.25$ & $46 \mathrm{~N} 34.84$ & 119W39.16 & 16.90 & 1.0 & $17 / 22$ & 77 & 3 & 0.08 & AA & $2.8 \mathrm{~km} \mathrm{NNW}$ of $200 \mathrm{West}$ \\
\hline 9912012011 & & $99 / 12 / 01$ & $20: 12: 12.14$ & $46 \mathrm{~N} 58.91$ & $119 \mathrm{~W} 17.57$ & 5.39 & -0.4 & $6 / 06$ & 235 & 11 & 0.16 & $\mathrm{CD}$ & 16.1 km S of Moses Lake \\
\hline 9912110707 & & $99 / 12 / 11$ & 07:07:59.94 & $46 \mathrm{~N} 36.67$ & 119W56.97 & 6.51 & 0.3 & $3 / 06$ & 280 & 14 & 0.09 & $\mathrm{AD}$ & $24.6 \mathrm{~km} \mathrm{WNW}$ of $200 \mathrm{West}$ \\
\hline 9912220933 & & $99 / 12 / 22$ & 09:33:31.66 & $46 \mathrm{~N} 36.34$ & $119 \mathrm{~W} 47.60$ & 7.88 & 1.1 & $13 / 16$ & 114 & 2 & 0.13 & $\mathrm{AB}$ & $13.0 \mathrm{~km} \mathrm{WNW}$ of $200 \mathrm{West}$ \\
\hline
\end{tabular}




\section{Explanation of Table 3.2}

EVENT ID: The Earthworm Recording System creates the identification number. XPED uses the year, month, day and time to create a unique number for each event.

TYPE: $\quad \mathrm{P}$ is Probable Blast; $\mathrm{X}$ is Confirmed Blast; $\mathrm{F}$ is Felt Earthquake; $\mathrm{H}$ is hand picked from helicorder; $\mathrm{S}$ is surficial event (rockslide, avalanche) and not a explosion or tectonic earthquake; blank is local earthquake.

DATE: The year and day of the year in Universal Time Coordinated (UTC). UTC is used throughout this report unless otherwise indicated.

TIME: The origin time of the earthquake given in UTC. To covert UTC to Pacific Standard Time, subtract eight hours; to Pacific Daylight Time, subtract seven hours.

LATITUDE: North latitude, in degrees and minutes, of the earthquake epicenter.

LONGITUDE: West longitude, in degrees and minutes, of the earthquake epicenter.

DEPTH: The depth of the earthquake in kilometers $(\mathrm{km})$.

MAG: $\quad$ The magnitude is expressed as Coda-Length magnitude $\mathrm{M}_{\mathrm{c}}$, an estimate of local magnitude $\mathrm{M}_{\mathrm{L}}$ (Richter 1958). If Magnitude is blank no determination could be made.

NS/NP: $\quad$ Number of stations/number of phases used in the solutions.

GAP: Azimuthal gap. The largest angle (relative to the epicenter) containing no stations.

DMIN: $\quad$ The distance from the earthquake epicenter to the closest station

RMS: $\quad$ The root-mean-square residual (observed arrival times minus the predicted arrival times) at all stations used to locate the earthquake. It is only useful as a measure of quality of the solution when five or more well-distributed stations are used in the solution. Good solutions are normally characterized by RMS values of less than about 0.3 seconds.

Q: $\quad$ The Quality Factors indicate the general reliability of the solution/location (A is best quality, D is worst). See Section 3.3 of this report: Quality Factors. 


\subsection{Geology and Tectonic Analysis}

The Hanford Site lies within the Columbia Basin, which is an intermontane basin between the Cascade Range and the Rocky Mountains that is filled with Cenozoic volcanic rocks and sediments. This basin forms the northern part of the Columbia Plateau physiographic province (Fenneman 1931) and the Columbia River flood-basalt province (Reidel and Hooper 1989). In the central and western parts of the Columbia Basin, the Columbia River Basalt Group (CRBG) overlies Tertiary continental sedimentary rocks and is overlain by late Tertiary and Quaternary fluvial and glaciofluvial deposits (Campbell 1989; Reidel and others 1989; DOE 1988). In the eastern part, a thin (<100 m) sedimentary unit separates the basalt and underling crystalline basement and a thin $(<10 \mathrm{~m})$ veneer of eolian sediments overlies the basalt (Reidel and others 1989).

The Columbia Basin has two structural subdivisions or subprovinces: the Yakima Fold Belt (YFB) and the Palouse Slope. The YFB includes the western and central parts of the Columbia Basin and is a series of anticlinal ridges and synclinal valleys with major thrust faults mainly along the northern flanks (Figure 4.1). The Palouse Slope is the eastern part of the basin and is the least deformed subprovince with only a few faults and low amplitude, long wavelength folds on an otherwise gently westward dipping paleoslope. Figure 4.2 shows north-south and east-west cross sections through the Columbia Basin based on surface mapping, deep boreholes, geophysical data (including the work of Rohay et al. [1985]), and magnetotelluric data obtained as part of BWIP (DOE 1988).

\subsection{Earthquake Stratigraphy}

Studies of seismicity at the Hanford Site have shown that the seismicity is related to crustal stratigraphy (layers of rock types) (Rohay et al. 1985; DOE 1988). The main geologic units important to earthquakes at Hanford and the surrounding area are:

- The Miocene CRBG

- The Paleocene, Eocene, and Oligocene sediments

- The crystalline basement (Precambrian and Paleozoic craton; Mesozoic accreted terranes).

\subsection{Geologic Structure Beneath the Monitored Area}

Between the late 1950s and the early 1980s, deep boreholes were drilled for hydrocarbon exploration in the Columbia Basin. These boreholes provided accurate measurements of the physical properties of the CRBG and the pre-basalt sediments (Reidel et al. 1989, 1994), but the thickness of the pre-basalt sediments and nature of the crystalline basement are still poorly understood. The difference between the thicknesses listed in Table 4.1 and the thicknesses of the crustal layers in the velocity model in Table 3.1 reflect data specific to the UW's crustal velocity model for eastern Washington. Table 4.2 is derived 


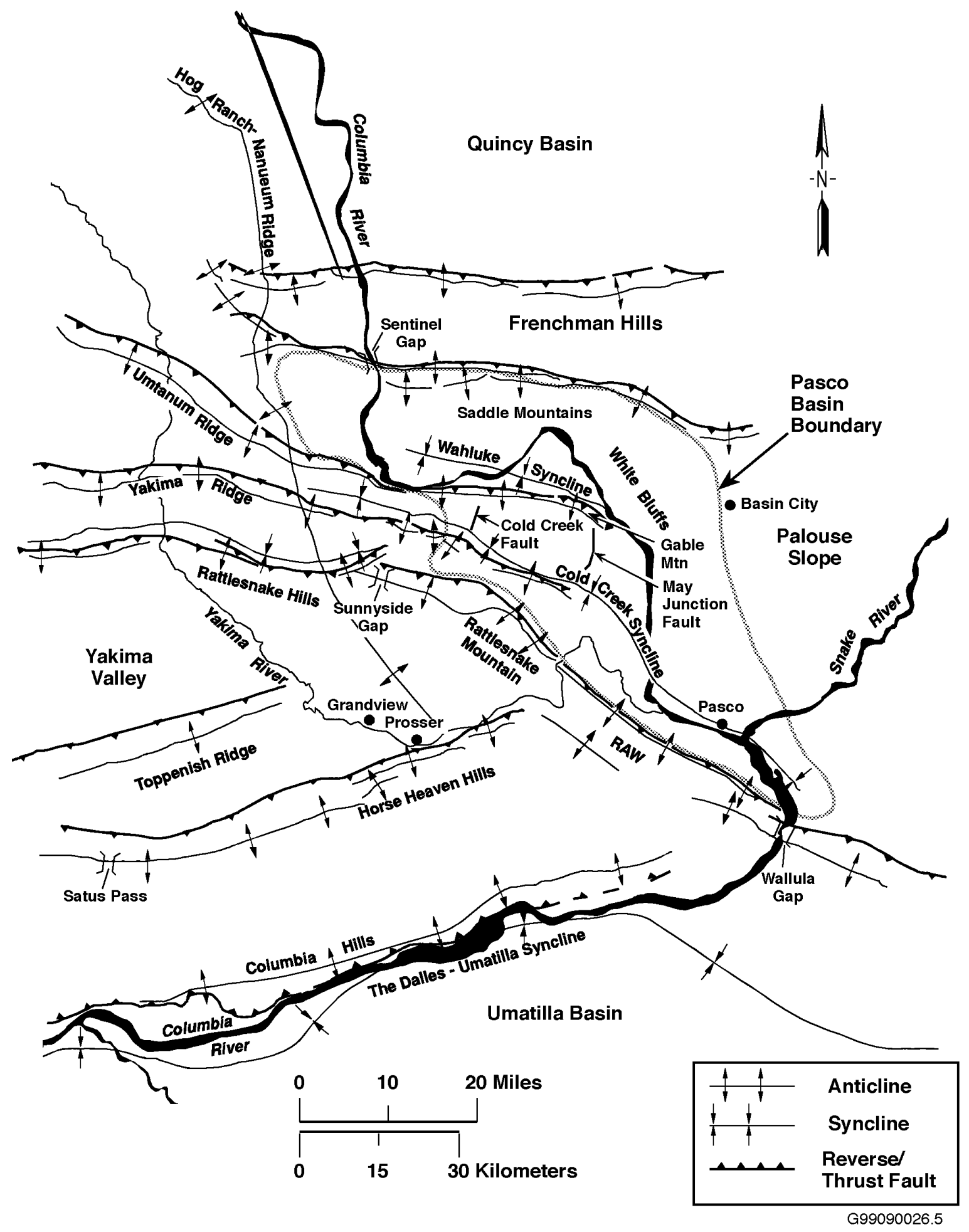

Figure 4.1. Structural and Tectonic Map of Columbia Basin Showing Major Seismic Source Structures 

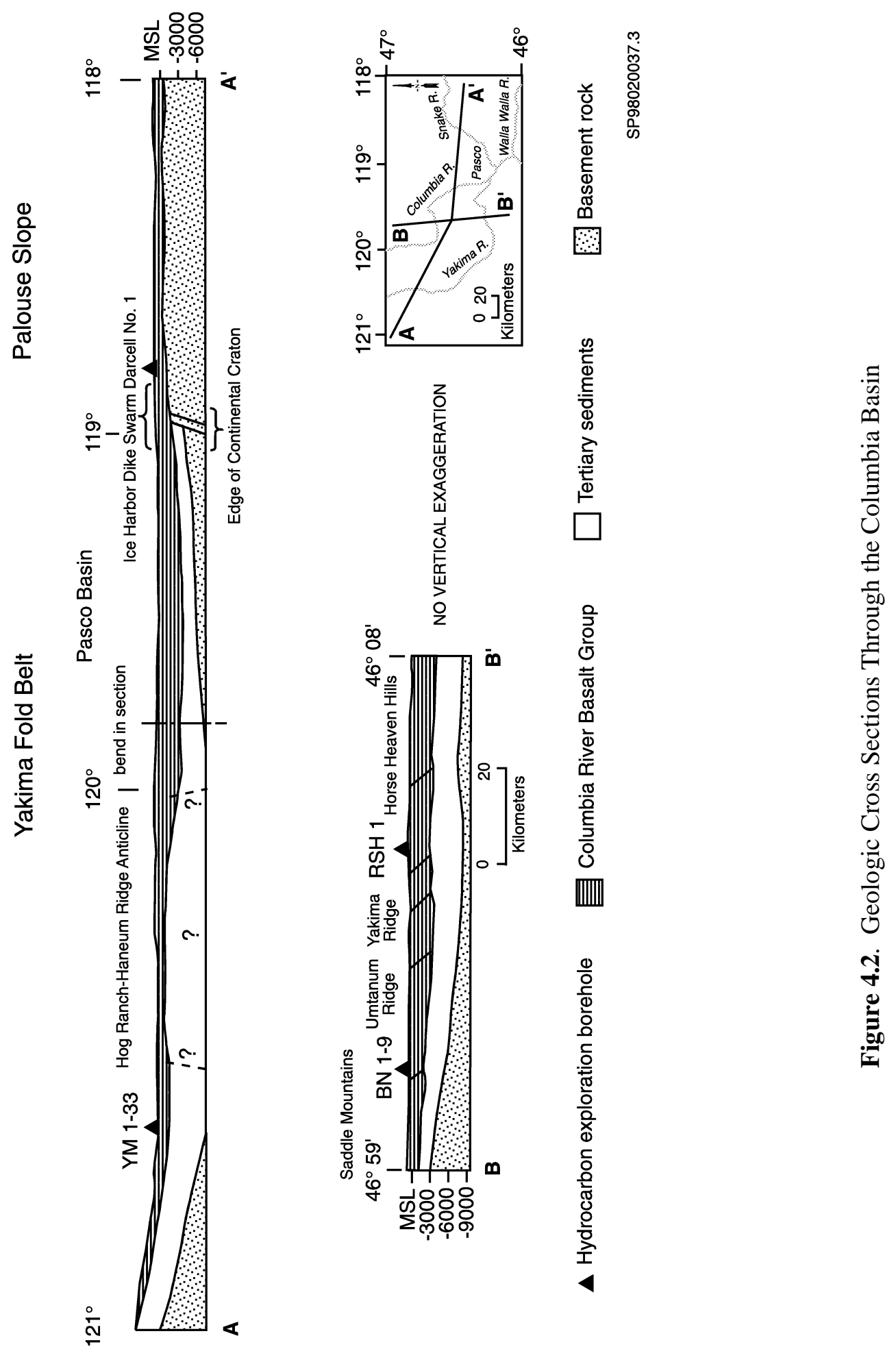
from Figure 4.2 and was developed for the geologic interpretation in this report. The thicknesses of these units are variable across the monitored area. Table 4.1 summarizes the approximate thickness at the borders of the monitored area.

Table 4.1. Thicknesses of Stratigraphic Units in the Monitoring Area

\begin{tabular}{||l|l|l|l|l||}
\hline \multicolumn{1}{|c|}{ Stratigraphy } & \multicolumn{1}{c|}{ North } & \multicolumn{1}{c|}{ South } & East & \multicolumn{1}{c||}{ West } \\
\hline \hline $\begin{array}{l}\text { Columbia River Basalt Group (includes } \\
\text { suprabasalt sediments) }\end{array}$ & $3.0 \mathrm{~km}$ & $4.5 \mathrm{~km}$ & $2.2 \mathrm{~km}$ & $4.2 \mathrm{~km}$ \\
\hline \begin{tabular}{l} 
Pre-basalt sediments \\
\hline
\end{tabular} & $3.0 \mathrm{~km}$ & $>4.5 \mathrm{~km}$ & 0 & $>6.0 \mathrm{~km}$ \\
\hline
\end{tabular}

The thickness of the basalt and the pre-basalt sediments varies as a result of different tectonic environments. The western edge of the North American craton (late Precambrian/Paleozoic continental margin and Precambrian craton) is located in the eastern portion of the monitored area. The stratigraphy on the craton consists of CRBG overlying crystalline basement; the crystalline basement is continental crustal rock that underlies much of the western North America. The stratigraphy west of the craton consists of 4-5 km of CRBG overlying greater than $6 \mathrm{~km}$ of pre-basalt sediments. This in turn overlies accreted terranes of Mesozoic age. The area west of the craton was subsiding during the Eocene and Oligocene, accumulating great thickness of pre-CRBG sediments. Continued subsidence in this area during the Miocene resulted in thicker CRBG compared to that on the craton. Subsidence continues today but at a greatly reduced rate (Reidel et al. 1994).

\subsection{Depth of Earthquakes}

Since records have been kept, about $75 \%$ of the earthquakes at the Hanford Site have originated in the CRBG layer. The pre-basalt sediments have had about $7 \%$ of the events and the crystalline basement has had 18\%. The stratigraphic units for local earthquakes recorded for FY 2000 are listed in Table 4.2.

Table 4.2. Number of Local Earthquakes Occurring in Stratigraphic Units

\begin{tabular}{|l|c|c|c|c|c||}
\hline \multicolumn{1}{|c|}{ Unit } & First Quarter & Second Quarter & Third Quarter & Fourth Quarter & FY 2000 \\
\hline \hline Basalt & 2 & - & - & - & $2(18 \%)$ \\
\hline Pre-basalt sediments & 3 & - & - & - & $3(27 \%)$ \\
\hline Crystalline basement & 6 & - & - & - & $6(55 \%)$ \\
\hline Total & 11 & - & - & - & 11 \\
\hline
\end{tabular}

\subsection{Tectonic Pattern}

Studies have concluded that earthquakes can occur in the following six different tectonic environments (earthquake sources) at the Hanford Site (Geomatrix 1996). 
- Reverse/thrust faults. Reverse/thrust faults in the CRBG associated with major anticlinal ridges such as Rattlesnake Mountain, Yakima Ridge, and Umtanum Ridge could produce some of the largest earthquakes.

- Secondary faults. These are associated with the major anticlinal ridges.

- Swarm areas. Small geographic areas of unknown geologic structure produce clusters of events (swarms), usually in the CRBG in synclinal valleys. These clusters consist of a series of small shocks with no outstanding principal event. Swarms occur over a period of days or months and the events may number into the hundreds and then quit, only to start again at a later date. This differs from the sequence of foreshocks, mainshock, and trailing-off aftershocks that have the same epicenter or are associated with the same fault system. Three principal swarm areas are known at the Hanford Site. One is the Wooded Island Swarm Area along the Columbia River near the 300 Area. The second area, the Coyote Rapids Swarm Area, extends from the vicinity of the 100-K Area north-northeast along the Columbia River Horn to the vicinity of the 100-N Area. The third major swarm area is along the Saddle Mountains on the northern boundary of the Hanford Site. Other earthquake swarm areas are present, but activity is less frequent.

- The entire Columbia Basin. The entire basin, including the Hanford Site, could produce a "floating" earthquake. A floating earthquake is one that, for seismic design purposes, can happen anywhere in a tectonic province and is not associated with any known geologic structure. It is classified as a random event by Seismic Monitoring for purposes of seismic design and vibratory ground motion studies.

- Basement source structures. Studies (Geomatrix 1996) suggest that major earthquakes can originate in tectonic structures in the crystalline basement. Because little is known about geologic structures in the crystalline basement beneath the Hanford Site, earthquakes cannot be directly tied to a mapped fault. Earthquakes occurring in the crystalline basement without known sources are treated as random events for seismic hazards analysis and seismic design.

- The Cascadia Subduction Zone. This source recently has been postulated to be capable of producing a magnitude 9 earthquake. Because this source is along the western boundary of Washington State and outside the HSN, the Cascadia Subduction Zone is not an earthquake source that is monitored at the Hanford Site, so subduction zone earthquakes are not reported here. Because any earthquake along the Cascadia Subduction zone can have a significant impact on the Hanford Site (Geomatrix 1996), the UW monitors and reports on this earthquake source for DOE. Ground motion from any moderate or larger Cascadia Subduction Zone earthquake is detected by seismometers in the HSN.

\subsection{Tectonic Activity}

The locations for earthquakes that occurred in the first quarter of FY 2000 are summarized in Tables 4.2 and 4.3 and are described in the following. 
Table 4.3. Summary of Earthquake Locations

\begin{tabular}{|c|c|c|c|c|c|c|c|}
\hline \multicolumn{3}{|c|}{ Seismic Sources } & $\begin{array}{c}\text { First } \\
\text { Quarter }\end{array}$ & $\begin{array}{l}\text { Second } \\
\text { Quarter }\end{array}$ & $\begin{array}{c}\text { Third } \\
\text { Quarter }\end{array}$ & $\begin{array}{l}\text { Fourth } \\
\text { Quarter }\end{array}$ & FY 2000 \\
\hline \multicolumn{3}{|c|}{ Geologic structures } & 2 & - & - & - & 2 \\
\hline \multirow{6}{*}{$\begin{array}{l}\text { Swarm } \\
\text { areas }\end{array}$} & \multicolumn{2}{|c|}{ Saddle Mountains } & 0 & - & - & - & 0 \\
\hline & \multicolumn{2}{|c|}{ Coyote Rapids } & 0 & - & - & - & 0 \\
\hline & \multicolumn{2}{|c|}{ Wooded Island } & 0 & - & - & - & 0 \\
\hline & \multirow{3}{*}{$\begin{array}{l}\text { Less } \\
\text { active } \\
\text { swarms }\end{array}$} & \multirow{3}{*}{$\begin{array}{l}\text { Wahluke } \\
\text { Slope } \\
\text { Horse Heaven } \\
\text { Hills } \\
\text { Benson Ranch }\end{array}$} & 0 & - & - & - & 0 \\
\hline & & & 0 & - & - & - & 0 \\
\hline & & & 0 & - & - & - & 0 \\
\hline \multicolumn{3}{|c|}{ Random events } & 9 & - & - & - & 9 \\
\hline
\end{tabular}

\subsubsection{First Quarter of FY 2000}

The locations of all mapped earthquakes that occurred from October 1, 1999 through December 31, 1999 are shown on Figure 4.3.

\subsubsection{Major Anticlinal Ridges}

During the first quarter of FY 2000, we interpret two seismic events (18\% of all events) to have occurred on major ridges. On November 11 , a small $\left(0.8 \mathrm{M}_{\mathrm{c}}\right)$, shallow earthquake occurred along the Rattlesnake-Wallula alignment of anticlines and faults southwest of Kennewick, Washington. This event was shallow and occurred in the CRBG. Although the location is of poorer quality (BD, Table 3.2) than we would prefer, we place the event on the nearest structure (Badger Mountain along the RAW, Figure 4.1) because of its close proximity and because it lies within a series of three closely spaced anticlines.

A small event (approximately $0 \mathrm{M}_{\mathrm{c}}$ ) occurred on December 1, 1999 along the north flank of the Frenchman Hills. This earthquake occurred in the basalt and was centered on O'Sullivan Dam. Young faults have been mapped in this area (Geomatrix 1996).

\subsubsection{Earthquake Swarm Areas}

No earthquakes occurred in any of the known swarm areas during the first quarter of FY 2000.

\subsubsection{Random or Floating Events}

There were 9 events (82\%) classified as random events this quarter because they did not occur in known earthquake swarm areas or along known geologic structures. Three events were in the pre-basalt sediments and six events were in the crystalline basement. No faults or folds have been identified below the basalt so events in the pre-basalt sediments and crystalline basement are classified as random events. 


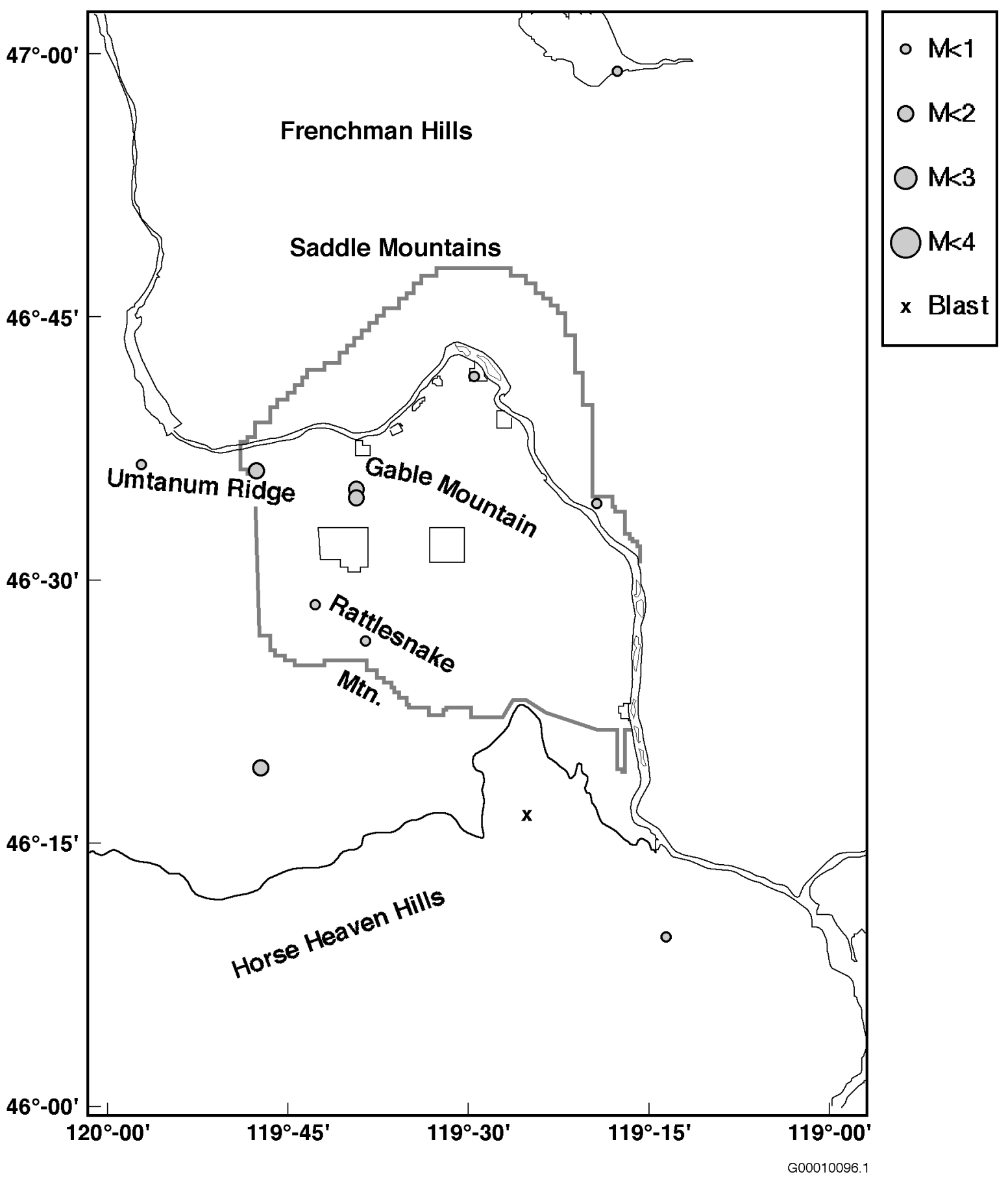

Figure 4.3. Locations of All Events From October 1, 1999 Through December 31, 1999 (Coda Length Magnitude $\left(\mathrm{M}_{\mathrm{c}}\right)$ scale is shown at the side of the map) 
On October 17, an earthquake occurred in the sediments below the CRBG on the south flank of the Rattlesnake Hills. This earthquake was small $\left(1.4 \mathrm{M}_{\mathrm{c}}\right)$ and $10 \mathrm{~km}$ from the crest of the fold. No known faults occur in this area.

Two events occurred along the Rattlesnake Mountain fault but both were over $18 \mathrm{~km}$ deep, which places them in the crystalline basement. The first event was small $(0.6 \mathrm{Mc})$ and occurred on October 27. It was west of Rattlesnake Mountain between sensor sites RSW and SNI (Figure 2.1). The second event was also small $(0.8 \mathrm{Mc})$ and occurred on October 31. It occurred $5 \mathrm{~km}$ northwest of the October 27 event very near site SNI (Figure 2.1).

On November 11, a small $\left(0.2 \mathrm{M}_{\mathrm{c}}\right)$, isolated event occurred $14 \mathrm{~km}$ deep in the crystalline basement near the eastern termination of Umtanum Ridge (Figure 4.1). On November 13, a second small (0.2 Mc) earthquake occurred $18 \mathrm{~km}$ north of the November 11 event, along the Columbia River. The second event also was in the crystalline basement. There is no known geologic structure near this event.

On November 21, two small events (1.6 and $1.0 \mathrm{M}_{\mathrm{c}}$, respectively) occurred within a minute of each other in the crystalline basement a few km northwest of the 200-West Area. Neither event is along any known geologic structure.

On December 11, a small $\left(0.3 \mathrm{M}_{\mathrm{c}}\right)$ event occurred in the pre-CRBG sediments under Yakima Ridge in the Cold creek valley. The earthquake was immediately below the surface exposure of the Yakima Ridge fault and south of the Umtanum Ridge fault. Because neither of these faults is thought to extend below the basalt, this earthquake is classified as a random event.

The last event for the quarter was a small event $\left(1.1 \mathrm{M}_{\mathrm{c}}\right)$ that occurred on December $2210 \mathrm{~km}$ east of the December 11 event. This earthquake also occurred in the pre-CRBG sediments and, for similar reasons as the December 11 event, it is classified as a random event. 


\subsection{Strong Motion Accelerometer Operations}

The Hanford SMA network was restarted November 20, 1999 after a one year hiatus. Since its restart, there were no earthquake triggers. The SMA network had several triggers resulting from noise. The number of triggers resulting from noise and normal human activity is being monitored to determine the optimal settings for the triggering system. Our objective is to minimize triggers caused by noise and maximize detection of very small magnitude earthquakes. 


\subsection{Capabilities in the Event of a Significant Earthquake}

The SMA network was designed to provide ground motion in areas at Hanford that have high densities of people and/or have hazardous facilities. This section summarizes the capabilities of the Seismic Monitoring Team in the event of an earthquake at Hanford.

\subsection{Use of the SMA Network in the Event of an Earthquake}

Historically, only a few facilities at the Hanford Site had instruments to provide data on peak ground accelerations or any type of ground motion. The present SMA instruments were located so that if an earthquake occurred, ground motion data would be readily available to assess the damage at the 100-K Area, the 200 East and West Areas, and the 300 and 400 Area facilities.

Many facilities at the Hanford Site have undergone various degrees of seismic analysis either during design or during re-qualification. Although the seismic design of a building may be known, when an earthquake is felt, a determination must be made as to the extent of damage before it can be reoccupied and the systems restarted. A felt earthquake may not cause any damage to a building but initial determination of possible damage may be impossible without adequate characterization of the ground motion.

In the event of an earthquake, building managers, emergency directors, and engineers can obtain ground motion data recorded by the SMA network from the Seismic Monitoring Team in Sigma V. If a SMA is triggered, the Seismic Monitoring Team will download events that were recorded and determine the peak ground accelerations and the spectral response curves. This information can then be used by the facility engineers to determine if the ground motion exceeded, was equal to, or was less than the building design. This, together with assessments from trained engineers, allows the facility manager to make a rapid and cost effective determination on whether a building is safe to reoccupy or should not be used until it has been inspected in more detail. Buildings that have designs exceeding the recorded ground motion could be put back into service very quickly; buildings with designs that are very close to or less than measured ground motion could be given priority for onsite damage inspections. 


\subsection{References}

Campbell, N. P. 1989. "Structural and stratigraphic interpretation of rocks under the Yakima fold belt, Columbia Basin, based on recent surface mapping and well data." In S. P. Reidel and P. R. Hooper (eds.), Volcanism and Tectonism in the Columbia River Flood-Basalt Province Geological Society of America Special Paper 239, pp. 209-222.

Crosson, R. S. 1972. Small Earthquakes, Structure and Tectonics of the Puget Sound Region. Bulletin of the Seismological Society of America, 62(5):1133-1171.

DOE. 1988. Site Characterization Plan for the Reference Location, Hanford, Washington-Consultation Draft. Report DOE/RW-0164, Vol. 1, U.S. Department of Energy, Washington, D.C.

Fenneman, N. M. 1931. Physiography of Western United States. McGraw-Hill, 534 p.

Geomatrix. 1996. Probabilistic Seismic Hazard Analysis, DOE Hanford Site, Washington. WHC-SDW236A-TI-002, Rev. 1, Westinghouse Hanford Company, Richland, Washington.

Moore, C., and S. P. Reidel. 1996. Hanford Site Seismic Monitoring Instrumentation Plan. WHC-SDGN-ER-30036, Westinghouse Hanford Company, Richland, Washington.

Reidel, S. P., and P. R. Hooper (eds.). 1989. Volcanism and Tectonism in the Columbia River FloodBasalt Province, Geological Society of America Special Paper 239, 386 p.

Reidel, S. P., N. P. Campbell, K. R. Fecht, and K. A. Lindsey. 1994. "Late Cenozoic Structure and Stratigraphy of South-Central Washington." In E. Cheney and R. Lasmanis (eds.), Regional Geology of Washington State, Washington Division of Geology and Earth Resources Bulletin 80, pp. 159-180, Olympia, Washington.

Reidel, S. P., K. R. Fecht, M. C. Hagood, and T. L. Tolan. 1989. “Geologic Development of the Central Columbia Plateau." In S. P. Reidel and P. R. Hooper (eds.), Volcanism and Tectonism in the Columbia River Flood-Basalt Province, Geological Society of America Special Paper 239, pp. 247-264.

Richter, C. F. 1958. Elementary Seismology, W. H. Freeman and Company, p. 768.

Rohay, A. C., D. W. Glover, and S. D. Malone. 1985. Time-Term Analysis of Upper Crustal Structure in the Columbia Basin, Washington. RHO-BW-SA-435 P, Rockwell Hanford Operations, Richland, Washington. 


\section{Distribution}

No. of

\section{Copies}

\section{OFFSITE}

Consolidated Information Center

Washington State University - Tri-Cities

100 Sprout Road

Richland, WA 99352-1643

J. Litehiser

Bechtel National, Inc.

P.O. Box 193965

San Francisco, CA 94119-3965

3 Oregon Department of Geology and Mineral Industries

Suite 965, 800 NE Oregon Street \#28

Portland, OR 97232

ATTN: J. Beaulieu

Library

I. Madin

S. Sobczyk

Nez Perce Tribe

P.O. Box 365

Lapwai, ID 83540

M. Stickney

Montana Tech University

Earthquake Studies Office

Butte, MT 59701

5 University of Washington

Geophysics Program

P.O. Box 351650

Seattle, WA 98195-1650

ATTN: R. Crosson

R. Ludwin

S. Malone

A. Qamar

R. Steele
No. of

\section{Copies}

2 U.S. Geological Survey

University of Washington

P.O. Box 351650

Seattle, WA 98195

ATTN: C. Weaver

T. Yelin

U.S. Geological Survey

Mail Stop 977

345 Middlefield Road

Menlo Park, CA 94025

ATTN: H. Stenner

4 Washington Division of Geology and Earth

Resources

P.O. Box 47007

Olympia, WA 98504-7007

ATTN: R. Lasmanis

C. Manson

S. Palmer

T. Walsh

Washington State University

Department of Geology

P.O. Box 643420

Pullman, WA 99164-2812

J. Zollweg

Boise State University

Department of Geosciences

Boise, ID 83725

Distr.1 
No. of

Copies

ONSITE

6 DOE Richland Operations Office

M. J. Furman

R. D. Hildebrand

J. E. Mecca

M. R. Moreno

K. M. Thompson

J. L. Tokarz-Hames

4 Bechtel Hanford, Inc.

V. J. Cueno

K. R. Fecht

P. J. Mackey

R. S. Rajagopal

\section{B\&W Hanford Company}

D. A. Conners

Duke Engineering \& Services, Inc.

R. Whitehurst II

R3-86

DynCorp Tri-Cities Services, Inc.

T. P. Morales

A3-05

2 Fluor Daniel Hanford, Inc.

B. R. Bowman

J. T. Curtis

H0-12

H0-12

R3-79

A5-55

$\mathrm{H} 0-12$

A5-55

H0-18

H0-02

B3-15

H0-18

T5-11
No. of

Copies

Fluor Daniel Northwest, Inc.

F. M. Mann

H0-22

16 Pacific Northwest National Laboratory

M. V. Berriochoa K9-56

D. C. Hartshorn K6-81

D. G. Horton K6-81

S. J. Kowall K8-12

W. J. Martin K6-81

P. E. Moore P7-63

S. P. Reidel K6-81

A. C. Rohay K6-81

R. M. Smith K6-96

Information Release Office (7) K1-06 